\title{
Digital Society, Social Change and Contestation in the Fight for Religious Authorities Between Muslim Generations: A Study of the Surakarta Muslim Communities
}

\author{
M Miftah ${ }^{1}$, B T Cahya ${ }^{2}$, M Marpaung $^{3}$, Satwarnirat ${ }^{4}$ \\ Institut Agama Islam Negeri (IAIN) Kudus ${ }^{1,2}$ \\ Institut Agama Islam Negeri (IAIN) $)^{3,4}$ \\ \{muhammadmiftah@stainkudus.ac.id ${ }^{1}$;cahyab380@gmail.com²; muslim.marpaung07@gmail.com³ \\ satwarnirat1966@gmail.com $\left.{ }^{4}\right\}$
}

\begin{abstract}
Surakarta is one of the regions in Central Java with a high-rank level of religious plurality. Many Islamic religious organizations have emerged and developed in this region so that they have created their own socio-religious dynamics for their followers in any level of society. The high social friction that occurs among people has made Surakarta an arena of contestation for religious authorities among Muslim generations mostly driven by Islamic organizations, both in the real and virtual (online) worlds. This contestation occurs through the way of truth claims that cause each Muslim generation to make a demarcation in economic, social, and religious-cultural aspects. This research aims to reveal and to map the expansion of the ideologies among the Muslim organizations in Surakarta through their social networks by which they attempt to seize influence over digital communities. It also will examine how the contestation has socio-religious impacts on the surface level.
\end{abstract}

Keywords: Religious Authority, Muslim Generation, Social Change

\section{Introduction}

Indonesia has become one of the most appropriate models used in the administration of democracy compared to other Muslim-majority countries. Indonesia's success in building a stable political democracy is a new development that has never happened in the history of the modern Islamic world [1]. While several Muslim countries in the world are still boisterous and uncertain in determining the system of government, Indonesia has been able to place a democratic system. Indonesia successfully implemented democracy as a tool in determining decisions and power without ignoring the roles and functions of an existing religion, including Islam as a religion of the majority with the rapid growth of Islamic organizations.

Historically, the rapid development of Islamic mass organizations began after the collapse of the New Order, which is marked by the strengthening of the religious values of Muslims which is often called Islamic Revivalism. This can be seen from the high interests of the communities in the 
form of worship, the spread of recitation, the spread of Islamic clothing, and the emergence of parties that use Islamic labels. The momentum of reform was also put to good use by radical Islamic movements, which gave rise to social dynamics that invited the attention of many people both in cyberspace and in the real world [2]. The same thing was experienced by Islamic organizations in Surakarta where the collapse of the New Order has awakened the 'lying down' cells of religious ideology.

The development of mass organizations can be seen from several factors that influence the growth and development of Islamic mass organizations in Surakarta, including a combination of historical, economic, political and sociological ones [3]. In addition to various external factors that influence the growth and development of Islamic organizations in Surakarta, the cultural community of Surakarta also contributes to the development of Islamic organizations in the region. The characteristics of the Surakarta society that are open and upholding religious values make these Islamic organizations feel comfortable in developing their wings. In this case, at least the Islamic mass organizations in Surakarta can be mapped into two large poles that are interacting and contest testing both in cyberspace and in the real world. The first is conservative Islamic mass organizations that aim to safeguard the culture and tradition that developed in the community. The second is modern Islamic movements, i.e. Islamic mass organizations (puritans) with their various variants.

It is interesting to discuss the various dimensions of social relations between Islamic mass organizations in Surakarta. Moreover, Surakarta has various variants of Islamic organizations with their own distinctive characteristics. It can be said that the development of Islamic mass organizations in Surakarta is very dynamic as each organization has characters and religious visions and missions that are opposing each other. Surakarta develops and even becomes the center of advertisement and patronage for mass organizations around the region. In addition to taking the benefits of its geographical aspects, Islamic mass organizations in Surakarta are also supported by a relatively stable climate of social conductivity.

The interaction of Islamic mass organizations in Surakarta has been developing not only within the boundaries of mutualism symbiotic relations, but it has also created a contestation both in the online and real worlds. Contestation and ideological war between Islamic organizations in Surakarta are taking place in the context of fighting for vision and mission as well as religious authorities in the society.

The patterns of religious authority have shifted from relations between the followers and the religious leaders. The emergence of new media information network (internet) began to displace the religious authority owned by the government through the Ministry of Religion and nongovernmental institutions such as community organizations (mass organizations) [4]. However, this thesis is not necessarily true, seeing that various Islamic organizations, religious leaders, even the Ministry of Religion also contribute to the contents of various social media platforms. That is, the new media becomes only a chamfer from the existing authority. Like NU that has NU Online (http://www.nu.or.id/), Muhammadiyah also runs Suara Muhammadiyah (http://www.suaramuhammadiyah.id/), and other organizations have social media spaces in developing and realizing its vision and mission.

The contestation, negotiation, and openness of the community in Surakarta in terms of social and religious life make this city very dynamic. This condition is at least influenced by an open political structure because of negotiation between the existing religious, social and political forces 
[5]. In this research, we want to examine how attitudes and behaviors come into cyberspace in struggling for religious authority among Islamic mass organizations in Surakarta, and how they affect the real world. The word used in referring to active Muslim societies who are following the development of technology is Generation M, to borrow Shelina Janmohamed's term. It should be kept in mind that not all Muslims are part of Generation M. Although the members of Generation $\mathrm{M}$ are mostly young, the age is not the barometer here. Instead, the attitudes and expertise in responding to technological developments, faiths, and modernity are the parameters.

The basic assumption of this research is that religion is a value system that can influence a person's behaviors in various aspects, both cultural, social, and even a worldview in life. Ideally, religion is used as a reference for identity that can give meaning to social interaction[6]. Therefore, it can be inferred that the upheaval that occurs is religious. The Islamic religious organizations in Surakarta contributed to the color of religious images in the face of the history of interaction among Muslims in Surakarta. Social interaction in the city of Surakarta is nuanced with religious symbols corresponding to the vision, mission, and interests of each mass organization. Thus, the contestation of religious discourse and ideology appears on various social media platforms and mass media, which ultimately affects the social attitudes of Muslim communities in the real world.

\section{Method}

This study is field research that uses a qualitative descriptive (exploratory) approach based on participatory observation of a social phenomenon. The researchers seek to compile or provide a clearer picture of the phenomena based on data collected and tested [7].

The data used in this research is qualitative which is conducted through deep interviews. This approach attempts to uncover and optimize the roles of competent parties in providing information related to the topics in this research. Qualitative research is assumed interpretive [8], as Taylor and Bogdan argued that "qualitative methodologies refer to research procedures which produce descriptive data: people's own written or spoken words and observable behavior" [9].

One characteristic that underlies qualitative research is that the world in general, reality, situation, or events or that occurs as objects of study of human behavior and phenomena must be approached and viewed through a humanistic approach [10]. The analysis therein uses a more closely descriptive model in which many data collected are in the form of words. The unit of analysis in this research is social change, digital society and contestation for the intergenerational religious authority of Muslims; and study of the Surakarta Muslim Community.

\section{Result and Discussion}

\section{Geographic Conditions of Surakarta City}

The city of Surakarta is located between $110^{\circ} 45$ "15" and $110^{\circ} 45$ "35" East Longitude and between $7^{\circ} 36$ "and $7^{\circ} 56^{\prime \prime}$ South Latitude. Surakarta City is one of the major cities in Central Java, which supports other cities such as Semarang and Yogyakarta. Surakarta City Region or better known as "Solo City" is a lowland with an altitude of $\pm 92 \mathrm{~m}$ above sea level. The total area of Surakarta City is $44.06 \mathrm{Km}^{2}$ and is administratively divided into 5 (five) subdistrict administration areas, 51 urban villages, $602 \mathrm{RW}$ and 2,708 RT. The administrative boundaries of the Surakarta City area, according to the Surakarta City RTRW 2007-2026 are as follows [11]. 
North

East

South

West

: Boyolali and Karanganyar Regencies;

: Karanganyar and Sukoharjo Regencies;

: Sukoharjo Regency;

: Sukoharjo, Karanganyar and Boyolali Regencies

Tabel 2.1 Division of Surakarta City Administration

\begin{tabular}{lrrrr}
\hline \multicolumn{1}{c}{ Districts } & Urban Village & $\begin{array}{c}\text { Area } \\
\left(\mathbf{K m}^{\mathbf{2}}\right)\end{array}$ & RW & \multicolumn{1}{c}{ RT } \\
\hline Laweyan & 11 & 8,64 & 105 & 457 \\
Serengan & 7 & 3,19 & 72 & 312 \\
Pasar Kliwon & 9 & 4,82 & 100 & 422 \\
Jebres & 11 & 12,58 & 151 & 646 \\
Banjarsari & 13 & 15,81 & 176 & 877 \\
Surakarta City & 51 & 44,06 & $\mathbf{6 0 4}$ & $\mathbf{2 . 7 1 4}$ \\
\hline
\end{tabular}

Source: Division of Public Administration of the Regional Secretariat of Surakarta, 2016

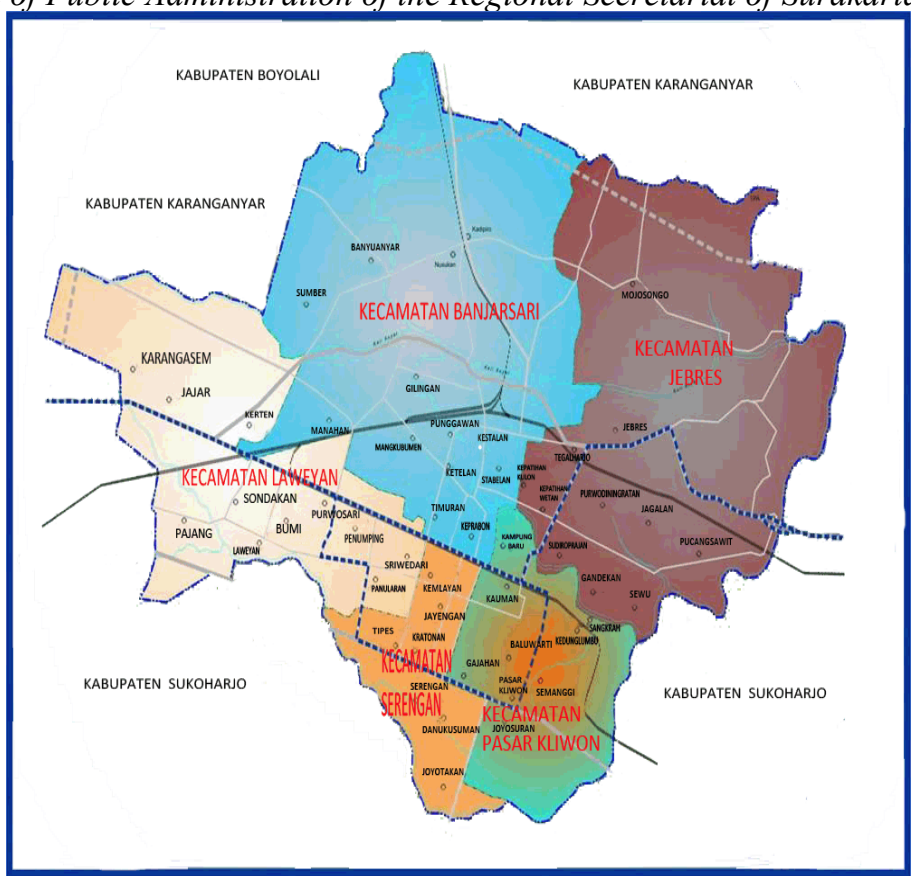

Figure 2.1.Map of Surakarta City

\section{Portrait of Muslim Generation in Surakarta}

The long journey of the political movement of Islamic organizations starting from the preindependence of Indonesia until now cannot be separated from the social and political aspects that surround it. Muslims (Islamic organizations) have an important role in the life of the nation and state[12]. The portrait of Islamic organizations in Surakarta greatly varied ranging from the

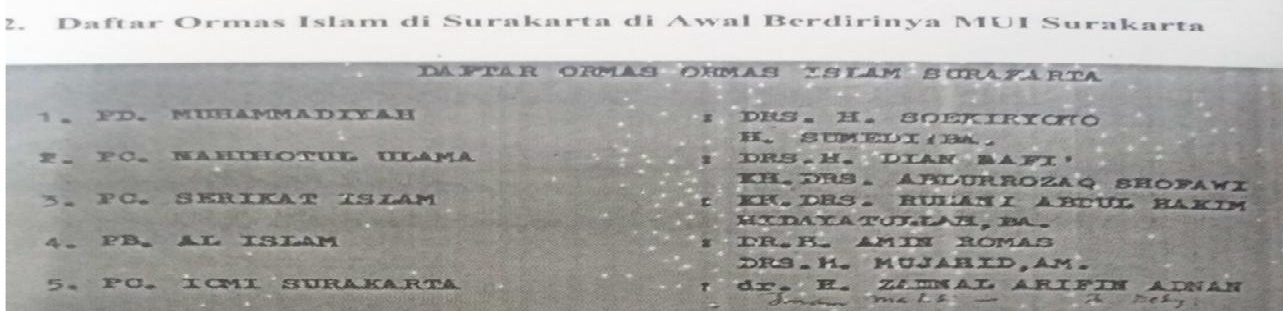


conservative, moderate, even radical, each of which has a distinctive vision, ideology, character, movement, and goals [13].

According to MUI Surakarta, the initial list of these mass organizations is as shown below:

From this data, we can roughly map that Islamic mass organizations in Surakarta in 1961 was no more than twenty officially registered mass organizations. The number is even higher at the present; some Islamic organizations do not register legally. In this case, these legal mass organizations are alleged including mass organizations labeled as radicalizes or hardliners.

Surakarta is known as a base of hardline Islamic organizations.in the early 2000s, there were many sweeping actions against all kinds of immoral places such as karaoke, massage parlors and all immoral activities [14]. In addition, Surakarta is also home to a growing number of puritanical and even radical religious groups as well as also religion-based civilian paramilitary groups who carry out actions that tend to be anarchist and are very unsettling to local residents [15]. Sweeping actions and demolition of immoral places have been quiet lately and done by mass organizations in Surakarta. Their actions are now more dominantly voicing the idea of public space by doing a series of long marches while carrying religious and organizational symbols.

The reality shows that MUI (the Indonesian Council of Ulama) in Surakarta established a good relation with the Islamic mass organizations, such as Muhammadiyah, NU (Nahdhatul Ulama), DDII (Indonesian Islamic Da'wah Council), SI (Islamic Union), ICMI (Indonesian Muslim Intellectuals Association), MTA (Al-Qur'an Interpretation Assembly) [16]. However, at the grassroots level, MUI Surakarta has not been able to make each of the followers of this mass organization give each other space to develop their teachings and maintain mutual peace.

It is also important to note the leniency and freedom supported by this reform era, especially among Islamic mass organizations in Solo Raya (Wonogiri, Sukoharjo, Klaten, Sragen, Boyolali). Research by Abu Hapsin found that there are around 28 Islamic mass organizations in Solo having the potential to become radical Islamic organizations. This statement at that time has caused unrest towards Islamic organizations in Solo Raya, especially Abu Hapsin himself who was the Chairperson of the Nahdlatul Ulama Region in Central Java. Of course, this will fuel the unrest and suspicion among Islamic organizations in Surakarta.

The contestation over religious authority in Surakarta is still at a conducive level and does not lead to a physical collision or open conflict. This is evident from the fact that during the celebration of the presidential election (Pilpres), Solo became the spotlight of the national media because of the potential conflicts between Islamic mass organizations. Each community organization, both openly and hiddenly, was actively involved in practical politics at the time. One 
of the Islamic organizations, LUIS (Laskar Umat Islam Surakarta), led by Edi Lukito, instructed to provide a sense of security after the presidential election through siding the decision in the Constitutional Court.

Besides, there was an effort to connect ukhuwah among Islamic organizations in Solo Raya. On March 10, 2013, Surakarta City Sharia Council (SCSC) was formed for the sake of unity in Surakarta.This is an independent organization that belongs to a scientific movement and publicity, whose goal is to realize Islamic sharia in Surakarta. However, this mission does not appear to be fully accepted by several Islamic organizations, because the existence of SCSC is indirectly alleged to have political content. This is what makes some Islamic organizations disagree with SCSC.

\section{Contestation of Religious Authorities between Muslim Generations}

It is natural that human beings have a tendency to uphold their beliefs. This is in line with what al-Ghazali said in his work al-Mungidz min al-Dhalal (Liberation from Heresy) that was written at the end of his life with high enthusiasm and passion for knowledge. Al-Ghazali asserted that human nature in religion at a certain point will typically follow his parents and teachers [17]. This thesis at least reinforces the importance of choosing communities or groups in studying religion correctly. Human understanding of diversity and religion is greatly influenced by the environment and education, which eventually form the patterns of thoughts and behaviors in interacting with the environment.

The development of religious awareness as a distinctive structure of meaning and a mode of self-understanding socially and politically also promotes the seeds of Indonesian nationalism. Dawam Rahardjo, for example, said that the influence of religious awareness or religious movements did not only give birth to nationalism but also brought up civil society [6]. On the contrary, distorted religious awareness will lead to endless unrest.

A truth claim any religion is very important but it should be simultaneously positioned as a functional truth. If this is not the case, the truth will narrow the space for religion itself [18]. Truth claims will shackle personal space for social interaction with other individuals who have different or opposing understandings. In Solo, the truth claims are pertinent in each Islamic organizations often referred to as Islamic fundamentalists. This is where the "root problem" lies, haunting the harmony between Islamic mass organizations in Solo Raya.

The term 'fundamentalist' was first embedded in evangelical Christian groups, such as those who are opposing the Darwinian theory of evolution. In its development after the outbreak of the Iranian revolution in 1978-1979, the term was attributed to the ideology of followers of Ayatollah Khomeini. Since then the terms' fundamentalist' and 'Islamic' seemed to be hardly separated [19]. The issue of anti-Muslim stereotypes is clearly apparent these days because it is often exploited by the media, and there is no strong authority in defending the Muslim world [19].

This stereotype is also one of the emotional triggers of radical Islamists who feel called to defend with all their potential. This defense is certainly not entirely wrong. However, it seems that they overreact in defending Islam, because of which violence is dominant colors in the defense by Islamic organizations in Surakarta.

The reaction that was manifested by Islamist groups (radical Islamic organizations) and the moderate Islamic groups in Surakarta here helped to enliven the contestation of religious discourse 
that has been developing in the public sphere, both in the real and online worlds. The new actors do their best to win the struggle for authority in the public discourse. During the New Order, the government took full control of the diversity discourse in society, but now thank the freedom of expression the government can no longer intervene in the public discourse. The consequence of this transformation is the emergence of new religious authorities that are competing with the old authorities in seizing public influence [20].

The struggle for authority, coupled with the development of information technology, has a significant impact on the choice of religious reference for the millennial generation. Information technology (internet) with its various social media platforms has been transformed into the heart of religious studies. The internet is an alternative to find answers to all the religious problems that are difficult to ask in traditional religion [21]. It is often that contestation on the internet was transformed into fighting for ideas between each mass organization in Surakarta to win influence and authority among the Generation M in Surakarta.

Generation $\mathrm{M}$ wants the world to know that faith affects everything. They are aware of the consequence that they must engage in dialogue with the ruling authorities regardless of geographical and cultural boundaries that restrict themselves from interacting with other communities [22]. The Generation M in Surakarta obtains knowledge from various sources, even though not entirely reliable, that eventually shape their mindsets in interacting and socializing with others. As Robert F. Kennedy said, the media is comparable to the court, which is to justify and punish. The worst thing is judgments made by generations in the real world. This is also the case with Generation M in Surakarta.

In the world of mass media, 'freedom of ideas is guaranteed by the constitution' has been a familiar term. Whereas, anyone enjoys freedom is indirectly having the social responsibility to carry out. Therefore, the press has the obligation to run certain essential functions [23]. The digital world is not the same. Although there has been an ITE Law, the government still failed to wipe out the content disruptive to the diversity and harmony between Islamic mass organizations.

The mass media has an important role as a means of social control and the maintenance of social order. The mass media holds an extensive and effective power to control people. Joseph Klapper, for instance, considers the presence of "conscious engineering" in the media where it can smooth coercion into an inducement and seduction [23]. This is what happens when reading a 'radical web page' which attempts to include negative contents by quoting verses of the Qur'an in order to make the Generation M in Surakarta profiled and ignited with a sense of belonging that gives rise to spontaneity in a variety of actions and reactions that are manifested in the real world.

The websites of some mainstream Islamic mass organizations, such as Muhammadiyah and $\mathrm{NU}$, are not popular for the users of social media, especially among the generations $\mathrm{Y}$ and $\mathrm{Z}$. These organizations are preaching peace, such as diversity, interfaith harmony, and social justice, Pancasila and nationalism. The case with contemporary organizations is that their websites are filled with organizational publicity interests and claims of justification rather than alternative narratives [24]. It is very different when looking at the web pages of radical mass organizations wherein the discussion on the state system and the national foundation of Indonesia is dominant.

The contents and narratives on the website created by Islamic mass organizations should place Islam more as social ethics and morals rather than laws. We must protect national, not Islamic, insights [25]. Social relations between religious communities are one element that must be addressed to realize a good social order. This relationship is not only normative but is a rational- 
humanistic. Thus, the approach taken in solving community problems must also be rational and humanistic [18].

Community organizations have been present and growing in line with the nation's historical development. In the course of the nation's history, they have become the main vehicle for movement. They serve as a means of controlling social conditions and a place to call for the fundamental freedoms for the individuals both in terms of formal ethical and legal frameworks protected and guaranteed by the State [26].

\section{Conclusion}

"Religion" has many faces and is no longer a matter of divinity, faith, and credo. Religion is closely related to historical-cultural contexts, which are inevitable for human beings [27]. These historical and cultural aspects have triggered relations and contestation between Islamic mass organizations in Surakarta. Contestation takes place through various social media platforms by targeting the Generation $\mathrm{M}$ who is actively following the development of technology.

There several factors that promoted conflicts between Islamic organizations in Surakarta: different individual characters, organizational, and situational conditions [28]. These three aspects indirectly affect the social relations in Surakarta. The contestation between Islamic organizations in Surakarta has no impact on the elites. However, the contestation is worrisome for the grassroots, like an "iceberg" that would explode at any time if there were no efforts from the elites to talk to their followers to maintain and respect each other's differences.

The clash arises when a particular group feels intimidated and denied by other groups to achieve its goals [29]. The struggle for the authority that gave rise to friction among the Muslim generation in Surakarta is taking place in the virtual and real-world because of excessive fanaticism among the followers of the mass organizations. Conflicts in Surakarta happened due to the intersection of religious values and stereotypes of mass organizations leading to suspicion and disharmony.

The state has the responsibility to maintain social harmony among its citizens. It can issue a package of religious policies and priority programs that can create a conducive climate and harmonious national life. On the other hand, religious leaders (Islamic organizations) should act as the broadcasters of wise teachings and should be in synergy so that the mission of religion as a peacemaker can be translated into the nation's life.

\section{References}

[1] A.-N. Permata and D. Qodir, Zuly, "Kegagalan dan Prospek Kepemimpinan Politik Islam di Indonesia Pasca Reformasi," in Kaum Muda Dan Kepemimpinan Indonesia Masa Depan, Yogyakarta: SUKA Press, 2013, p. 209.

[2] K. Zada, Islam Radikal: Pergulatan Ormas-Ormas Islam Garis Keras Di Indonesia. Jakarta: Teraju, 2002.

[3] M. Wildan, "The Nature of Radical Islamic Groups in Solo," vol. 7, no. 1, 2013.

[4] M. Jinan, "New Media dan Pergeseran Otoritas Keagamaan Islam di Indonesia," J. Lekt. Keagamaan, vol. 10, no. 1, pp. 181-208, 2012.

[5] Y. Puspidep, "Diseminasi Hasil Peneitian, PERSEPSI ULAMA TENTANG NEGARA- 
BANGSA: OTORITAS, NEGOSIASI DAN RESERVASI," Jakarta, 2018.

[6] A. Gunawan, Gerakan Keagamaan dalam Penguatan Civil Society Analisis Perbandingan Visi dan Misi LSM dan Ormas Berbasis Keagamaan. Jakarta: LSAF, 1999.

[7] A. Tanzeh, Pengantar Metode Penelitian. Yogyakarta: Teras, 2009.

[8] J. W. Creswell, Research Design: Pendekatan Kualitatif, Kuantitatif Dan Mixed. Yogyakarta: Pustaka Pelajar, 2010.

[9] M. Nazir, Metode penelitian. Jakarta: Ghalia Indonesia, 2003.

[10] S. Nasution, Metode Peneltian Naturalistik. Bandung: Tarsito, 2008.

[11] Dispendukcapil, "Kota Surakarta Dalam Angka Dan Data." 2016.

[12] Y. Latif, Intelegensia Muslim Dan Kuasa, Genealogi Intelegensia Muslim Indonesia Abad Ke-20. Bandung: Mizan Pustaka, 2005.

[13] Zulfadli, "Kontestasi Ormas Islamis Di Indonesia," Al-Tahrir J. Islam. Thought, 2019.

[14] Baidi, "Agama Dan Multikulturalisme: Pengembangan Kerukunan Masyarakat Melalui Pendekatan Agama (Edisi Khusus).” 2010.

[15] J. Tri Haryanto, "Relasi, Transformasi Dan Adaptasi Tradisionalis Terhadap Puritanisme Di Surakarta Jawa Tengah," vol. 22, no. 2.

[16] H. Maftuh, "Aktifitas Majelis Ulama Islam Indonesia (MUI) Dalam Perkembangan Kehidupan Keagamaan Di Surakarta 1975-2015," vol. 2, no. 1. 2015.

[17] M. Hasan Khalil, Islam and the Fate of Others: The Salvation Question, Oxford. University Press, 2012.

[18] S. Sirait, Dari Islam Inklusif Ke Islam Fungsional Telaah Atas Pemikiran Al-Faruqi. Yogyakarta: Datamedia, 1998.

[19] C. W. Ernst, Pergulatan Islam Di Dunia Kontemporer Doktrin Dan Peradaban. Bandung: Mizan Pustaka, 2016.

[20] H. Noorhaidi, Literatur Keislaman Generasi Milenial Transmisi, Apropriasi, Dan Kontestasi. Yogyakarta: Pascasarjana UIN Sunan Kalijaga, 2018.

[21] G. R. Bunt, HAShTAGH ISLAM How Cyber-Islamic Environments Are Transforming Religious Authority. The University of North Carolina press, 2018.

[22] S. Janmohamed, Generation M: Young Muslims Changing The World. London: I.B. Touris, 2016.

[23] W. L. Rivers, Media Massa Dan Masyarakat Modern. Jakarta: Kencana Prenada Media Group, 2008.

[24] Y. dkk Khisbiyah, Kontestasi Wacana Keislaman Di Dunia Maya Moderatisme, Ekstremisme, dan Hipernasionalisme. Surakarta: Pusat Studi Budaya dan Perubahan Sosial Universitas Muhammadiyah Surakarta, 2018.

[25] D. F. Eickelmen and J. Piscatori, "Muslims Politics." Prinveton University Press, 1996.

[26] D. Zainuddin, "ANALISIS PENANGANAN KONFLIK ANTAR ORGANISASI KEMASYARAKATAN DI SUMATERA UTARA (MEDAN) DAN JAWA TENGAH (SURAKARTA)," J. HAM, vol. 7, no. 1, pp. 10-20, 2016, doi: https://doi.org/10.30641/ham.2016.7.10-20.

[27] M. A. D. Abdullah, "Relevansi Studi Agama-Agama Dalam Milenium Ketiga," in Mencari Islam: Studi Islam Dengan Berbagai Pendekatan, Yogyakarta: Tiara Wacana, 2000.

[28] H. L. Tosi and N. P. Mero., The Fundamentals of Organizational Behavior: What 
Managers Need to Know. Malden, Massachussetts: Blacwell Publishing, 2003.

[29] G. R. Jones, Organizational Theory, Design, and Change, 5th ed. New Delhi: Dorling Kindersley, 2009. 